\title{
ANTITRUST, THE GIG ECONOMY, AND LABOR MARKET POWER
}

\author{
MARSHALL STEINBAUM*
}

I

\section{INTRODUCTION: DECLINING LABOR POWER Is (PARTLY) AN ANTITRUST STORY}

Worker bargaining power has diminished over the last forty years. Between 1948 and 1979, median wages closely tracked output per worker. ${ }^{1}$ Since then, productivity has continued to increase (until leveling off in the decade of the 2000s), while median pay has stagnated, creating an ever-widening gap between median wages and productivity. The widening gap contrasts with the central prediction of neoclassical economic theory about the labor market: that workers are paid what they are worth. ${ }^{2}$ At the same time, inequality within the distribution of labor income is higher, and has risen faster, than can possibly be explained by any notion of a skills gap between workers and the needs of today's employers. ${ }^{3}$ And since the 2000s, these dual trends demarcating the declining bargaining power of workers in the economy have been joined by a third: the reduction in labor's share of national income, which economists had assumed was stable over the long run. In fact, it has ratcheted downward over the last two business cycles. ${ }^{4}$

The aim of this paper is to augment the interpretation of these trends with an element that has received very little attention from labor-oriented scholars: the decline and erosion of antitrust law and its enforcement. Whereas there was once a sharp line where labor law ended and antitrust began, there is now a gray area, within which a more powerful firm can tell a less-powerful contractor or worker what to do without being liable under antitrust or labor law. The erosion of the statutory employment relationship, and thus the ability of employers to evade the

Copyright (C) 2019 by Marshall Steinbaum.

This article is also available online at http://lcp.law.duke.edu/.

* University of Utah, msteinbaum@gmail.com. Thank you to Sanjukta Paul, Brian Callaci, Alex Rosenblat, Catherine Fisk, and participants in the Duke Law and Contemporary Problems "Legal Framework of Work After the End of Employment" symposium, March 2019.

1. See The Productivity-Pay Gap, ECON. POL'Y InsT. (August 2018), https://www.epi.org/productivity-pay-gap/ [https://perma.cc/6NWC-3RV3].

2. Id.

3. Thomas Piketty, Emmanuel Saez \& Gabriel Zucman, Distributional National Accounts: Methods and Estimates for the United States, 133 Q. J. ECON. 2, 533-609 (2018).

4. David Autor et al., The Fall of the Labor Share and the Rise of Superstar Firms, (Nat'l Bureau of Econ. Res., Working Paper No. 23396, 2017); Simcha Barkai, Declining Labor and Capital Shares (2016) (unpublished manuscript) (on file with the Stigler Center for the Study of the Economy and the State). 
obligations that go along with it, has received wide attention from labor scholars and in public debate. What has been ignored is that the deterioration of antitrust is what legally allows more powerful firms to tell subordinate firms, contractors, and workers what to do even if those subordinates are not, legally, their employees. Antitrust has also prevented those same subordinates from coordinating among themselves to strengthen their own hand in negotiations.

This paper considers two different ways that antitrust has contributed to the increasing imbalance of power between employers and workers. First, antitrust has legalized vertical restraints, allowing the economy's most powerful actors to closely direct and supervise the behavior of less-powerful actors. Second, antitrust has been used by those same powerful actors to prevent less-powerful actors from organizing and coordinating on their own behalf against such concentrations of power. Parts II and III of this article deal with each of these, and the Part IV proposes a policy agenda for putting the antitrust laws to work in the labor market according to their original purpose: namely, to deconcentrate economic power.

\section{II}

\section{VERTICAL RESTRAINTS AND THE FISSURED WORKPLACE}

David Weil's book The Fissured Workplace describes a crucial component of the decline in labor's bargaining power: the gradual disappearance of the traditional, and statutory, employment relationship. ${ }^{5}$ Instead of uniting workers at different levels of the labor market hierarchy (wages, skills, and social prestige), the contemporary corporation has become a mechanism for segregating low-wage (and even some middle-wage) workers from the economy's dominant decision-makers: the executives and shareholders of the economy's leading corporations and the financial institutions that own and control them. Although most workers remain statutory employees of some employer, they are increasingly remote from the decision-making entity that exerts power over their day-to-day lives and terms of work. ${ }^{6}$

Weil is himself a former senior official responsible for enforcing federal labor law, and he rightly points to the ease with which employers can evade that law by re-classifying workers as either independent contractors or as employees of their contractors as a crucial element in legalizing this fissured business model. ${ }^{7}$ Many other scholars and organizations, including worker organizations, have emphasized changes in labor law that are very important to understanding how these trends erode worker bargaining power in the economy and ensure that it takes the form of inter-firm wage segregation. ${ }^{8}$ Specifically, the National Labor

5. DAVID WEIL, THE FISSURED WORKPLACE: WHY WORK BECAME SO BAD FOR SO MANY AND WHAT CAN BE DONE TO IMPROVE IT (2014).

6. Id.

7. Id.

8. Nelson Lichtenstein, Two Cheers for Global Integration: Corporate Governance in a World of Global Supply Chains, in CORPORATIONS AND AMERICAN DEMOCRACY 329-58 (2017); MAYA PINTO, 
Relations Act ${ }^{9}$ and the Fair Labor Standards Act, ${ }^{10}$ as well as numerous other state and federal labor regulations, impose tests for statutory employment as a necessary precondition for a worker to enjoy their protections. Increasingly, employers who classify their workers as exempt contractors rather than employees are able to pass these tests, thanks to deferential court rulings, ${ }^{11}$ technologies that enable employers to manage workers from afar, and industry deregulation that legalizes new, vertically dis-integrated business models in a given sector, among many other causes. These all give employers both the legal means and the pecuniary motive to push their workers outside the legal boundaries of the firm under whose effective control they remain.

Weil's research is classified methodologically as industry case studies of what he calls the "lead firms" that direct and control a series of contractors and affiliates that actually employ the workers and do the work. His findings have been confirmed by more traditional economics studies of inter-firm earnings inequality using matched employer-employee data from a variety of sources. ${ }^{12}$ For instance, Song and others used social security records to document the rise in inter-firm inequality; increasingly, the highest-paid workers work for the firms where average pay is the highest. ${ }^{13}$ This is not because those firms are inherently more productive than other firms due to their firm-specific characteristics, but rather that they have gotten better at sorting out well-paid and highly-educated workers and excluding low- and middle-wage workers from their employment. ${ }^{14}$ A study by Abowd and others of data from state unemployment insurance records verifies these distinctions, and attaches further significance to working at a well-paid firm. Not only do workers earn more now, but they do so for the rest of their careers. ${ }^{15}$ "High-paying firms facilitate moving workers to the top of the earnings distribution and keeping them there." ${ }^{16}$ Labor market surveys paint a similar picture. ${ }^{17}$

In a competitive labor market, the identity of a worker's firm is irrelevant to what he or she gets paid, because if any worker were paid less than they were worth they would quickly switch to a job offering them their competitive market wage. In a competitive labor market equilibrium, all firms pay the same to all

REBECCA SMITH \& IRENE TUNG, Rights AT RISK: Gig COMPANIES' CAMPAIGN TO UPEND EMPLOYMENT AS WE KNOW IT (2019) https://www.nelp.org/publication/rights-at-risk-gig-companiescampaign-to-upend-employment-as-we-know-it/ [https://perma.cc/9KHV-XWRD].

9. National Labor Relations Act, 49 Stat. 449 (1935).

10. Fair Labor Standards Act, 55 Stat. 756 (1941).

11. Lawson v. Grubhub, Inc., 2017 U.S. Dist. LEXIS 106291.

12. Id.

13. Jae Song et al., Firming Up Inequality, 134 Q. J. ECON. 1, 1-50 (2019).

14. Id.

15. John M. Abowd et al., Earnings Inequality and Mobility Trends in the United States: Nationally Representative Estimates from Longitudinally Linked Employer-Employee Data (Nat'l Bureau of Econ. Res., Working Paper No. 23224, 2017).

16. $I d$.

17. See Damir Cosic, Wage Distribution in Large and Small Firms (November 21, 2017) (unpublished manuscript) (on file with the International Labour Review). 
workers with similar characteristics. In reality, though, firms have considerable discretion to dictate pay, because outside job offers are sufficiently hard to obtain that it is unlikely that workers will have the option to leave. ${ }^{18}$ In other words, labor markets are not competitive, as evidenced by the increasing earnings inequality between firms. The aforementioned research on inter-firm inequality shows that workers are increasingly remote from profits and from centers of economic power..$^{19}$ Anyone familiar with the history of labor organizing, worker solidarity, and the conditions for social mobility can recognize that under those conditions, it's impossible for workers to benefit from economic growth. An article from the New York Times in 2017 made this point by contrasting the experience of janitors working at the corporate headquarters of Kodak in the early 1980s versus Apple today. The Kodak janitor was employed by the company, enjoyed a tuition subsidy as part of her benefits package, learned how to use inventory software as part of obtaining a college degree on the job, and ultimately worked her way up within Kodak to be head of IT for the whole company. ${ }^{20}$ Meanwhile, the Apple janitor is employed by a contracted, franchised janitorial services firm, enjoys no part of the benefits package of an Apple employee, and has no chance of obtaining a promotion up the hierarchy of what is now one of the economy's most valuable single firms. ${ }^{21}$

The antitrust side of the story of the separation of workers from lead firms is the simultaneous erosion in the jurisprudence of the Sherman Act's prohibitions on vertical restraints. In the context of antitrust, a vertical restraint is a contractual provision or mode of operation that restricts the autonomy of the counterparty in the case where each party operates at a distinct segment of the supply chain. For example, if an automobile manufacturing company operates a network of independently owned dealerships, and its dealers are forbidden from selling within a given radius of another authorized dealer's location, that is territorial exclusivity, a non-price vertical restraint. If such a contract imposes the final retail price of said automobiles, that is vertical price-fixing, or in antitrust lingo, resale price maintenance, which can be either a minimum or a maximum (or both, in the case of one definite price at which the car would be re-sold). Other vertical restraints include the varieties of exclusive practices that suppliers might impose on their affiliated dealers or distributors, like compulsory purchase contracts-known as full-line forcing or requirements contracts. ${ }^{22}$

\footnotetext{
18. Abowd et al, supra note 15 .

19. Id.

20. Neil Irwin, To Understand Rising Inequality, Consider the Janitors at Two Top Companies, Then and Now, N.Y. TIMES: THE UPSHOT (September 3, 2017), https://www.nytimes.com/2017/09/03/upshot/to-understand-rising-inequality-consider-the-janitors-attwo-top-companies-then-and-now.html [https://perma.cc/Q83S-VWWK].

21. Id.

22. See Charlotte Slaiman, Decoding Antitrust Law: A Primer for Advocates (2019), https://www.publicknowledge.org/documents/decoding-antitrust-law-a-primer-for-advocates [https://perma.cc/KL5C-9ZEG]
} 
Such exclusive dealing was the subject of the 1951 antitrust case United States v. Richfield Oil $\mathrm{Co}^{23}$ The case concerned the relations between a dominant oil refiner and gasoline supplier-Richfield Oil-and its affiliated service stations, which were required to source their gasoline solely from Richfield and to carry exclusively retail auto parts, sponsored products, according to supply contracts negotiated by Richfield, rather than seeking out and negotiating their own sources of supply according to their customers' preferences. The court ruled unequivocally for the government on the grounds that it exercised de facto control over these "independent business men," in contravention of the antitrust laws, despite the fact that they were not employees of the company. That case created a sharp distinction and a comprehensive delineation between the realm of labor and antitrust: if subordinate entities are "independent business men" and not employees, it is illegal to exercise control. The United States Supreme Court affirmed the same basic principle against coercion of non-employees by vertical supply contract in the 1964 case Simpson v. Union Oil Co. of California. ${ }^{24}$

It is precisely through the erosion of the Richfield Oil standard that the fissured workplace has been allowed to come about. Independent business people are independent for the purposes of evading labor law, but once pushed outside the border of the firm, the restrictions antitrust places on their domination have been all but erased. As such, what Weil calls lead firms can continue to exercise control and direct their business operations by contract. ${ }^{25}$ Those contracts would once have been illegal, before antitrust jurisprudence began to search out spurious justifications for their immunity on the basis of supposed efficiency. ${ }^{26}$ For example, manufacturers would want their branded distributors to be bound by contractual provisions to ensure that dealers represent the brand effectively to customers, rather than hide their poor customer service behind the brand's overall prestige, or that they must contribute to its marketing budget and abide by its standardized branding and pricing policies. Theoretically, this would serve the overall collective interest of the supplier-distributor network. The efficiencies to be gained by permitting franchisors to exercise overall direction and control were assumed to flow eventually to consumers in the form of increased output, enhanced variety or quality, or lower prices-all reflecting the fact that vertical control exercised this way is, in fact, pro- rather than anti-competitive and therefore ought not to be penalized by the antitrust laws. ${ }^{27}$

23. See United States v. Richfield Oil Corp., 99 F. Supp. 280 (S. D. Cal., 1951), aff'd, 343 U.S. 922 (1952).

24. See Simpson v. Union Oil Co. of California, 377 U.S. 13 (1964).

25. WEIL, supra note 5 .

26. See Lester Telser, Why Should Manufacturers Want Fair Trade?, J. L. ECON. 86 (1960); Thomas R. Overstreet, Resale Price Maintenance: Economic Theories and Empirical Evidence, Bureau of Economics Staff Report to the FTC (1983).

27. See Roger D. Blair \& Francine LaFontaine, The Economics of Franchising, 291301 (2005) (containing an explicit argument for permitting franchisors to exercise vertical control in these ways). 
Brian Callaci lays out how this process occurred in one sector, so-called business-format franchising. ${ }^{28}$ As he writes, "While the economic boundaries of the firm correspond to the extent of centrally planned and hierarchically coordinated production, the legal boundaries are set in politically contested legislatures and courts. Exploiting or creating mismatches between the two has enabled corporations to enjoy economic benefits of vertical integration while avoiding many of the legal risks and costs. ${ }^{29}$ In the case of franchising, that took the exact form that courts had ruled illegal in Richfield Oil and Simpson v. Union Oil Co. of California: franchisors licensed their trademarks and business models to an army of franchisees, who would be granted exclusive territories in exchange for agreeing to exclusive supply contracts, all enforced by the threat of dealer terminations.

Economists, particularly those operating in the Law and Economics tradition, have interpreted the rise of these hybrid structures, part firm, part market organizations, as reflecting the evolution of an efficient allocation of coordination rights and the alignment of incentives between principal and agent so as to remove the need for direct supervision and take advantage of economies of scale and specialization. ${ }^{30}$ But Callaci shows that, in fact, the advent and spread of franchising was not due to the law catching up with the natural evolution of a business model marked by superior efficiency. Rather, it is due to a concerted lobbying campaign ${ }^{31}$ to pry apart the sharp border between labor and antitrust represented by Richfield Oil and grow a whole business model in the legal gray area. ${ }^{32}$ As far as antitrust was concerned, the operation was meant to roll back the per se illegality of non-price vertical restraints that existed in antitrust following the Supreme Court's ruling in United States v. Arnold, Schwinn \& Co. in 1967, and the per se illegality for maximum resale price maintenance that existed following the Court's ruling in Albrecht v. Herald Company in 1968. ${ }^{33}$ With the Court's decisions in Continental Television v. GTE Sylvania in 1977 and in State Oil Co. v. Khan in 1997, antitrust immunity for vertical integration by contract was complete. ${ }^{34}$

It was not just antitrust where franchisors and their trade association were able to have their way. In 1966, the Small Business Administration re-classified franchisees as independent to avail themselves of subsidized federal loans,

28. Brian Callaci, Control Without Responsibility: The Legal Creation of Franchising 1960-1980 (December 2018) (unpublished manuscript) (on file with the Washington Center for Equitable Growth).

29. Id.

30. See generally ROGER D. BLAIR \& DAVID L. KASERMAN, LAW AND ECONOMICS OF VERTICAL INTEGRATION AND CONTROL (1983); BLAIR \& LAFONTAINE, supra note 27; Francine LaFontaine \& Margaret Slade, Exclusive Contracts and Vertical Restraints: Empirical Evidence and Public Policy, in HANDBOOK OF ANTITRUST ECONOMICS, 29 (Pablo Buccirossi ed., 2005).

31. Callaci, supra note 28, at 4 .

32. LaFontaine \& Slade, supra note 30.

33. See Albrecht v. Herald Co., 390 U.S. 145 (1968); United States v. Arnold, Schwinn \& Co., 388 U.S. 365 (1967).

34. See State Oil Co. v. Khan, 522 U.S. 3 (1997). 
despite concerns that this was essentially financing the marketing and distribution activities of some of the economy's largest and most powerful corporations..$^{35}$ The general counsel to the agency, Philip F. Zeidman, who had advocated internally for that policy change, subsequently served as counsel to the International Franchise Association for almost four decades. ${ }^{36}$ Just last year, the inspector general of the SBA concluded that its loans to poultry growers are likely illegal because those small businesses are in fact under such direct control from the major poultry integrators-Perdue, Tysons, and Koch Poultry-that the farmers cannot be considered small businesses. ${ }^{37}$

In addition to their treatment of franchisees as independent in order to qualify them for subsidized loans, the franchisors were successful at limiting the definition of joint employer under the National Labor Relations Act and the Fair Labor Standards Act so that they could not legally be considered employers of their franchisees' workers. ${ }^{38}$ That made any attempt by workers to bargain collectively against both franchisees and franchisors a secondary boycott, a practice expressly prohibited by the Taft-Hartley Act. ${ }^{39}$ Altogether, these changes gave franchisors maximum control, but minimal responsibility, and led the business models of franchisees toward poor treatment of low-wage workers, since franchisees have few, if any other margins, in which to exercise their autonomy in order to increase profits.

Recently, the issue of no-poaching restrictions in franchising contracts has drawn attention from researchers, ${ }^{40}$ elected officials, ${ }^{41}$ and antitrust enforcers. ${ }^{42}$ In such contracts, franchisees commit not to hire workers employed by franchisees elsewhere in the franchising network of which they are a member. Correspondingly, the Antitrust Division of the Justice Department has made its view known to a federal court where private litigation against such a no-poach provision is underway. It argued that no-poaching provisions in franchise agreements are akin to other restrictive vertical contractual provisions in franchising contracts and hence subject to the rule of reason, the permissive standard put in place by Continental Television v. GTE Sylvania and State Oil Co.

35. Callaci, supra note 28 , at 13 .

36. Id. at 21 .

37. OfF. OF THE InSPector Gen., SMAll Bus. Assoc., Evaluation of SBA 7(A) LoAns Made TO POULTRY FARMERS (March 6, 2018).

38. Econ. Policy Inst., Comment Letter on Proposed Rule Regarding Standard for Determining Joint-Employer Status (Feb. 8, 2019), https://www.epi.org/publication/joint-employer-comments-feb2019/ [https://perma.cc/84FQ-FGBV].

39. Labor Management Relations Act, 61 Stat. $136 \S 8$ (b)(4)(b) (1947).

40. See, e.g., Brian Callaci, Vertical Power and the Creation of a Fissured Workplace: The Case of Franchising (November 14, 2018) (unpublished manuscript) (on file with the Washington Center for Equitable Growth); Alan B. Krueger \& Orley Ashenfelter, Theory and Evidence on Employer Collusion in the Franchise Sector (Nat'l Bureau of Econ. Res., Working Paper No. 24831, 2017).

41. See, e.g., S. 2480, 115th Cong. (2018).

42. See, e.g., Corrected Statement of Interest of the United States of America, Stigar v. Dough Dough, Inc., No. 2:18-cv-00244-SAB (E.D. Wash. March 8, 2019). 
v. Khan. ${ }^{43}$ The DOJ specifically rejects the idea that franchising networks are hub-and-spoke arrangements, ${ }^{44}$ therefore that no-poach clauses might be horizontal agreements not to compete and thus illegal per se. This intervention by the DOJ leans against the relatively pro-enforcement posture it expressed in 2016 in its "Guidance for Human Resource Professionals." 45 The prior administration never stated whether no-poaching provisions in franchising contracts were to be treated as per se illegal or considered under the rule of reason. But alongside the unwillingness of the NLRB to extend dual-employer status to franchisors as well as franchisees (and notwithstanding a recent federal appellate ruling constraining its ability to do so), ${ }^{46}$ this use of no-poach clauses reflects powerful employers' ability to direct and restrict the activities and employment of their workers, without being answerable in any way to those workers themselves.

The contentions the DOJ makes in its statement of interest are in conflict with the economics of no-poaching agreements in labor markets where employer market power is pervasive. ${ }^{47}$ There is no functional difference between a series of uniform, bilateral, putatively vertical no-poaching agreements, collectively barring franchisees in a franchising network from hiring workers from elsewhere in the network, and a single multilateral, putatively horizontal no-poaching agreement between the individual franchisees. Those two things have the same anti-competitive effect on labor markets. Thus, antitrust law should not treat them differently based on the horizontal versus vertical formalism. The DOJ brief appeals to the potential for countervailing efficiencies that swayed the Supreme Court to abandon per se treatment of non-price vertical restraints in Continental Television v. GTE Sylvania. Notably, however, those ostensible benefits accrue to consumers, not to workers, if they accrue to anyone at all other than the company imposing the restraint. If antitrust law implicates competition in labor markets as well as competition in output markets, as the DOJ agrees is the case, then it should not justify anti-competitive restraints that harm workers by making the labor market less competitive by claiming they might benefit consumers. ${ }^{48}$ Moreover, the amicus curiae brief filed by the Attorney General of Washington State points out that franchising networks contain both franchisorowned and franchisee-owned establishments, rendering a no-poaching agreement binding on franchisees likely to restrain them from hiring retail

43. Id.

44. See Fed. Trade Comm'N \& DeP'T OF Just., ANTitrust GuidanCE FOR Human Resource PROFESSIONALS (2016).

45. Id.

46. See Rachel M. Cohen, Workers Just Notched a Rare Win in Federal Court, THE INTERCEPT (January 2019), $\quad$ https://theintercept.com/2019/01/03/nlrb-joint-employer-ruling/ [https://perma.cc/33WE-TM36].

47. See generally José Azar et al., Measuring Labor Market Power Two Ways, AEA PAPERS \& PROCEEDINGS (forthcoming May 2019); Arindrajit Dube et al., Monopsony in Online Labor Markets, AER: INSIGHTS (forthcoming June 2019); Douglas A. Webber, Firm Market Power and the Earnings Distribution, 35 LAB. ECON., 123-134 (2015).

48. See Fed. Trade Comm'N \& DeP'T OF Just, supra note 44. 
workers employed by franchisors. ${ }^{49}$ Altogether, the pending litigation over franchising no-poaching agreements highlights antitrust's tolerance for restraints that bind both franchisees and their workers. This belies recent claims by several antitrust authorities that labor markets and product markets are treated symmetrically under current antitrust jurisprudence and enforcement. ${ }^{50}$ They are not.

More recently than the expansion of franchising under permissive antitrust treatment is the advent of the so-called gig economy: the deployment of independent contractor status for workers, not just for the independent businesses who employ them. This makes each individual worker an independent business, and thus denuded of any protections under labor law. However, they can simultaneously be controlled entirely by employer/customers without the protections and stability of the employment relationship enshrined in statute during the New Deal. This is the business model that online labor platforms like Uber, Lyft, Handy, and Care.com have perfected: under the law, workers deal bilaterally with gigs whose employers have none of the standard obligations of employers, while the platform operates the entire labor market to its own benefit - what Sanjukta Paul has called a "for-profit hiring hall." ${ }^{11}$ This is enabled by the GPS technology of monitoring workers, the ability of the platform to dictate the terms on which participants will transact, the use of customer ratings as a pretext for de-activation rather than direct supervision, and the immunity of all of this from any regulatory scrutiny or collective bargaining on the part of workers of any sort.

In 2016, an Uber customer filed an antitrust suit against Uber $^{52}$ and its CEO in New York claiming that it amounted to a price- and wage-fixing conspiracy among hundreds of thousands of independent businesses - its drivers, for whom Uber determines and dictates the terms on which its drivers are allocated customers and the prices that will be charged to them, including the share earned by the driver..$^{53}$ The genesis of the suit was the repeated failed efforts to have drivers classified as employees under state and federal labor regulations. To defeat those suits, Uber claimed to be a software company licensing its service

49. Brief for the Attorney General of Washington as Amicus Curiae, Stigar v. Dough Dough, Inc., No. 2:18-cv-00244-SAB (E.D. Wash. March 11, 2019).

50. See C. Scott Hemphill \& Nancy L. Rose, Mergers That Harm Sellers, 127 YALE L.J. 7, 2078 (2018); Letter from Federal Trade Commission Acting Chairman Maureen Ohlhausen to Senator Cory Booker (December 1, 2017) (on file with author).

51. Sanjukta M. Paul, Uber as For-Profit Hiring Hall: A Price-Fixing Paradox and Its Implications, 38 BERKELEY J. EMP. \& LAB. L. 2, 233, 233 (2017).

52. The suit was initially filed against just the CEO, Travis Kalanick, as a means to avoid the mandatory arbitration clause that eventually kicked the case out of court, but Uber was later joined as a defendant.

53. Marshall Steinbaum, Uber's Antitrust Problem, The American ProspeCt (May 11, 2016), https://prospect.org/article/uber\%E2\% $80 \% 99$ s-antitrust-problem [https://perma.cc/8SPD-YBJD]; Marshall Steinbaum, Antitrust Implications of Labor Platforms, CPI ANTITRUST CHRONICLE (May 2018), https://www.competitionpolicyinternational.com/wp-content/uploads/2018/05/CPI-Steinbaum.pdf [https://perma.cc/Y2EY-49CS]. 
to independent drivers for the ease of contacting potential customers. As such, they did not employ the drivers, nor did Uber directly provide transportation to customers.

If drivers are not employees, so the theory behind the antitrust suit went, then they must be independent businesses, and hence Uber setting the terms on which they transact with customers, including fixing the prices charged to customers, constitutes a violation of the Sherman Act's ban on restraints of trade. In this respect, the plaintiff was helped by the precedent set by the Apple E-books antitrust case, which proceeded against Apple and five book publishers for conspiring to set up an alternative E-books platform to Amazon's. ${ }^{54}$ That case was ruled to be a hub-and-spoke conspiracy and thus per se illegal. ${ }^{55}$ If Apple and five book publishers is hub-and-spoke, why not Uber and a hundred thousand drivers? ? $^{56}$

In the end, Meyer v. Kalanick, was sent to arbitration rather than litigation thanks to the mandatory arbitration clause included in Uber's terms of service. Therefore, the issue of whether Uber is a price-fixing conspiracy, and whether that price-fixing is horizontal, was never resolved at trial. But Uber did commission at least two economics papers that signal what its antitrust defense would have been: Uber's control over its drivers, including price-fixing, benefits customers because it increases the consumer surplus in the ridesharing market. ${ }^{57}$

This illustrates the core reason why all of these business models that subordinate the interests of workers, franchisees, and suppliers generally to those of dominant buyers obtain immunity from antitrust law as it is currently interpreted: the consumer welfare standard, which holds that the sole metric for assessing harm to competition within the meaning of the antitrust laws is the effect on consumers, and in practice, the effect on prices charged to consumers. ${ }^{58}$ If the restrictions operated by Uber, by franchisors, by poultry integrators, and by powerful businesses generally can be shown to benefit consumers, or at least not to harm them, then they are ipso facto immune from antitrust liability.

This constriction of what the antitrust laws prohibit is a far cry from Richfield Oil, which contains an overt analysis of power dynamics in the supplierdistributor relationship as the reason why antitrust must lean against such a

54. United States v. Apple, Inc., 952 F. Supp. 2d 638 (2013).

55. Id.

56. On the other hand, in the Apple E-books case, the publishers organized among themselves as part of negotiating the entry of Apple's rival e-books platform. Arguably this is not the case with Uber or other ridesharing platforms, or labor platforms generally, in which there is no meaningful agreement among the many gig workers.

57. See, e.g., Peter Cohen et al., Using Big Data to Estimate Consumer Surplus: The Case of Uber (Nat'l Bureau of Econ. Res., Working Paper No. 22627, 2016); Jonathan V. Hall et al., Labor Market Equilibration: Evidence from Uber (October 27, 2017) (unpublished manuscript) (on file with authors).

58. Marshall Steinbaum \& Maurice E. Stucke, The Effective Competition Standard: A New Standard for Antitrust, ROOSEVELT INSTITUTE (2018), http://rooseveltinstitute.org/wpcontent/uploads/2018/09/The-Effective-Competition-Standard-FINAL.pdf [https://perma.cc/W6DXU6NH]. 
concentration of power on behalf of the dominant entity. ${ }^{59}$ Instead, the attenuated conception of economics that has developed more recently within legal reasoning and jurisprudence-consumer welfare and price effects as the sole criterion of harm to competition-explains much of how the labor market and the economy generally got to where it is today. In particular, how workers and contractors have been prevented from accessing the profits generated by the economy's leading firms through the exercise of unilateral power to dictate the contractual terms. Thanks to that, workers suffer from wage stagnation and a deterioration in job quality, including total control by the entity that is, economically, if not legally, their boss.

Two further aspects of the ridesharing platform business model are worth pointing out here: surveillance and non-linear driver pay structures. In the summer of 2018, a team of company-affiliated economists released yet another paper pointing to Uber's ostensibly efficiency-enhancing business model. ${ }^{60}$ The researchers compared the tendency of Uber drivers to shirk by taking longerdistance routes between the same two endpoints to the tendency of New York City taxi drivers to do the same. The meaningful differences between the two groups consisted of routes taken for fares originating at LaGuardia Airport and terminating in Manhattan. The researchers found that Uber drivers tend to shirk less than do taxi drivers, which they attribute to the fact that both Uber itself and the customer in the back seat can monitor the driver in real time using GPS, whereas traditional taxi drivers retain more discretion, and apparently use it to increase their take-home pay at riders' expense. But the ability to monitor employees in real time is part of both the statutory definition of employment and the economic concept of control. According to the paper, Uber's use of monitoring technology to improve the service enjoyed by its customers is exactly the context in which we would recognize that an employment relationship exists and grant rights to the employee. ${ }^{61}$ Instead, Uber drivers remain subordinate to Uber, which sets their fares and the share they take home. Taxi drivers, on the other hand, are normally also independent contractors, but they are genuinely more independent in that they are not monitored in real time. And neither they nor the medallion owner (if the driver does not own his own medallion) has discretion to set prices. Instead, fares in the taxi market are regulated.

Uber was also found to be operating a program nicknamed "Hell" that monitored whether drivers were multi-homing (i.e., logging into more than one ridesharing platform simultaneously to choose between competing fares) or single-homing and penalized the ones that were not taking customers on the Uber platform exclusively. ${ }^{62}$ More generally, the ridesharing companies operate bonus-

59. Richfield Oil Corp., 99 F. Supp. 280.

60. Meng Liu et al., Do Digital Platforms Reduce Moral Hazard? The Case of Ubers and Taxis, (Nat'l Bureau of Econ. Res., Working Paper No. 25015, 2018).

61. Id.

62. Ignacio Herrera Anchustegui \& Julian Nowag, Buyer Power in the Big Data and Algorithm Driven World: The Uber \& Lyft Example, COMPETITION POLICY INTERNATIONAL (Sept. 15, 2017), https://www.competitionpolicyinternational.com/buyer-power-in-the-big-data-and-algorithm-driven- 
based driver pay policies with a low base rate and a bonus for achieving a certain acceptance rate, or service in a given geographic area. ${ }^{63}$ This system effectively requires sole use of a single app and following that app's directions about where and when to work in order to win. While not technically requiring exclusivity on the part of drivers, this pay structure makes it very likely. ${ }^{64}$ And while such exclusive dealing (and market division, if there were to be any agreement to engage in similar non-linear bonus-based pay policies between Uber and Lyft) might be thought to implicate antitrust, those companies have seemingly faced no public enforcement since the Meyer $v$. Kalanick case was forced into arbitration.

These instances of increasing control of drivers by ridesharing platforms correspond to the general picture of ride-sharing employment that Alex Rosenblat paints in her recent book Uberland.$^{65}$ Rosenblat argues that the labor platforms are re-making the terms of employment to their own liking, exercising power over price-setting, quality and terms of service, and all manner of other relevant margins to customers and to workers, while disclaiming all responsibility. ${ }^{66}$ Initially, Uber and similar online labor platforms presented themselves as neutral market-makers matching drivers to customers, ameliorating the search frictions inherent in any labor market through the innovative application of new technology. ${ }^{67}$ Now, though, the platforms present their contribution to public welfare more as arising directly from their control over the market and its participants, rather than from their neutral facilitation of bilateral transactions. This hybrid business model of total control but no responsibility as an employer is one optimized not only to the erosion of labor protections, but also to the erosion of antitrust's restrictions on vertical restraints. In fact, it is highly reminiscent of the arguments found in the Law and Economics literature validating antitrust's increasing permissiveness toward vertical restraints on the grounds that the concentration and consolidation of power within the economy is economically efficient. ${ }^{68}$ However, there's nothing optimal or efficient about it, other than the efficient use of regulatory arbitrage to dominate and extract rents from every other counterparty and stakeholder in the market without having to follow the laws that bind everyone else.

world-the-uber-lyft-example/ [https://perma.cc/FHR7-KJPG].

63. See Alex Rosenblat, Uberland: How Algorithms Are Rewriting the Rules of WORK 138-166 (2018).

64. Julian Nowag, When Sharing Platforms Fix Sellers' Prices, 6 J. ANTITRUST ENF'T 3, 382-408 (2018).

65. See RosEnBLAT, supra note 63.

66. Id.

67. See Nicholas Buchholz, Spatial Equilibrium, Search Frictions, and Dynamic Efficiency in the Taxi Industry (July 23, 2018) (unpublished manuscript) (on file with Princeton University) (presenting Uber and similar platforms as reducing search frictions).

68. See Telser, supra note 26; Overstreet, supra note 26; BLAIR \& KASERMAN, supra note 30. 
III

\section{ANTITRUST AND COLLECTIVE BARGAINING IN THE GIG ECONOMY}

The erosion of antitrust in the direction of permitting vertical price- and nonprice restraints has effectively legalized labor outsourcing, misclassification, and the gig economy. This has resulted in dominant firms having access to a wider range of profitable business models that exert greater power and control over workers than they once did. Fundamentally, this trend within antitrust is in the direction of increasing the power of the economy's most powerful actors.

The flip side of this is that antitrust law has also made it more difficult for less powerful actors to collectively mitigate such power inequities. Sandeep Vaheesan refers to Albert Hirschman to make this point: not only has antitrust made it harder for workers and small businesses to exit in order to exercise countervailing power; it has also prevented them from using voice to do so. ${ }^{69}$ All of the mechanisms of concentrated power described in Part II could be categorized as curtailing workers' use of exit strategies to evade the control of their employers. This Part focuses on antitrust's dual opposition to worker voice.

Between the passage of the Sherman Act in 1890 and the Norris-LaGuardia Act in 1932, the federal antitrust enforcers used the former to curtail the collective bargaining activities of militant (and effective) labor organizing. In 1892, the Supreme Court ruled that the Workingmen's Amalgamated Council of New Orleans was illegal coordination by labor groups in violation of the Sherman Act's ban on restraints of trade. ${ }^{70}$ In 1894, the Cleveland Administration accused Eugene V. Debs, the head of the American Railway Union, of entering into criminal restraints of trade for organizing the Pullman Strike, including a nationwide boycott of trains carrying Pullman Cars. In fact, as the Supreme Court ultimately ruled on the case, the Sherman Act proved to be unnecessary: the Court held that the government could obtain an injunction against the strike and imprisonment of Debs without any statutory authorization, as it amounted to an exercise of its legitimate law enforcement powers to crush civil unrest. ${ }^{71}$

Likewise, in the 1908 case Loewe v. Lawlor, a company that had been targeted by a nationwide boycott on the part of the American Federation of Labor successfully sued the union trying to obtain recognition as its workers' bargaining agent under the Sherman Act. ${ }^{72}$ The Supreme Court agreed that such a boycott was an illegal restraint of trade and forced the union and its members to pay treble damages to their employer. ${ }^{73}$ These three cases show that the antitrust laws were a potent weapon in the hands of employers seeking to prevent unionization. During the same period, the government struggled half-heartedly to find a way to use the Sherman Act to limit corporate power, but it moved

69. Sandeep Vaheesan, Accommodating Capital and Policing Labor: Antitrust in the Two Gilded Ages, Md. L. Rev. (forthcoming).

70. United States v. Workingmen's Amalgamated Council of New Orleans, 54 U.S. 994 (1892).

71. In re Debs, 158 U.S. 564 (1985).

72. Loewe v. Lawlor, 208 U.S. 274 (1908).

73. Id. 
decisively, with the full cooperation of the judiciary, to use it to curtail labor power. ${ }^{74}$

The Clayton Act of 1914 included an exemption for labor from the antitrust laws, ${ }^{75}$ but courts interpreted it narrowly such that secondary boycotts were still illegal. ${ }^{76}$ It was not until the Norris-LaGuardia Act that unions were entirely immunized from antitrust liability. But in the jurisprudence of the so-called labor exemption that developed in the decade or so thereafter, antitrust immunity came to be connected to statutory employment status, like the right to collectively bargain itself. $^{77}$ Therefore, in the current era of the erosion of statutory employment, we also have the erosion of the antitrust labor exemption.

The Federal Trade Commission has undertaken a long-running campaign against collective action by associations of professionals who seek to constrain entry, and in some cases, to forbid their members from soliciting business away from fellow members and to set minimum prices for their services. The commission has brought such cases against doctors, church organists, ice-skating instructors, music teachers, and public defenders. ${ }^{78}$ This enforcement line has accompanied a push by the agency to reduce state action, meaning the regulatory authority of states or municipalities to displace competition in favor of some other legitimate policy goal, notwithstanding prohibitions in federal law. For example, municipal taxi regulatory regimes, which limit the total number of taxis on the road, impede entry into the taxi business. However, this impediment has the legitimate purpose of preventing market saturation, thereby ensuring that driving a taxi is a viable full-time job. It also hopefully ensures that coverage is universal in both time and space and that a customer unfamiliar with the city can obtain a licensed and qualified professional rather than an unsafe or just unqualified service provider. Some of the FTC's campaign against restrictions on competition in the market for service professionals consisted of attacks on licensing regimes that effectively protect incumbents and limit competition. The FTC's "economic liberty task force" is devoted to this, as was the case the FTC litigated to the Supreme Court in 2015 and won: North Carolina Board of Dental Examiners. ${ }^{79}$ The ruling held that a state board consisting primarily of members of the profession being regulated could not benefit from the state action exemption. ${ }^{80}$

74. See MARtin J. SKlar, The Corporate Reconstruction of American CAPitAlism, 1890-1916 (1988).

75. Clayton Antitrust Act, 15 USCS $\S \S 1-12$ (2006).

76. Duplex Printing Press Co. v. Deering, 254 U.S. 433 (1921).

77. See Sanjukta M. Paul, The Enduring Ambiguities of Antitrust Liability for Worker Collective Action, 47 LOY. U. CHI. L.J. 969 (2016).

78. See Sandeep Vaheesan, How Contemporary Antitrust Robs Workers of Power, L. \& P. ECON. BLOG (July 19, 2018), https://lpeblog.org/2018/07/19/how-contemporary-antitrust-robs-workers-ofpower [https://perma.cc/84MQ-Q4XZ].

79. N.C. State Bd. of Dental Exam'rs v. FTC 135 S. Ct. 1101 (2015).

80. Id. 
Even before the recent campaign against the state action exemption, the FTC involved itself in efforts by independent contractors to organize themselves in response to the trucking deregulation that de-unionized the sector in the late 1970s. Port truckers aspired to bargain collectively against logistics companies that were coordinating trucking services on behalf of powerful wholesalers and retailers and subjected them to low pay, long hours, and thus high turnover. The FTC as well as quasi-public entities like port authorities intervened on behalf of those companies and accused the truckers of violating the Sherman Act during organizing drives in the late 1990s and 2000s. ${ }^{81}$ This stance is consonant with the rationale behind trucking and transportation deregulation in the first place: that inefficient suppliers, middlemen, and stakeholders were preventing efficiencies attending to unitary control from being realized in regulated industries. Therefore, competition in the deregulation era would drive down the rents being earned by those insiders. Permitting truckers to bargain collectively as contractors once they had been de-unionized would have sacrificed all those supposed gains. The FTC also dissuaded Ohio from passing a state law that would have allowed independent contractor home health aides to bargain collectively with staffing companies and their clients in $2008 .^{82}$

The logic for these types of enforcement decisions can be found in the consumer welfare standard, just as was the case for vertical restraints imposed by dominant firms: protecting consumers is all that matters, and consumers are protected best when the most efficient firms have sufficient power and discretion to control the market, including at multiple levels of the supply chain, without having to reckon with any other stakeholder. On this reasoning, collective action by port truckers, home health aides, church organists, or gig economy workers is inefficient rent-seeking, and antitrust action against it "protects competition, not competitors." The superior efficiency to be found in, for example, Uber having the power to surveil, direct, and fix prices for its drivers, despite their independent contractor status, would be threatened if drivers had the power to mediate that surveillance or price-setting through any kind of co-determination.

It is against this background of hostility to state and local regulation and collective bargaining that the FTC and the Department of Justice intervened in another antitrust case involving Uber. After the lawsuits alleging employment misclassification against Uber had been sent to arbitration, the Seattle City Council passed an ordinance granting collective bargaining rights to ridesharing drivers who are not employees. ${ }^{83}$ The Chamber of Commerce, acting on behalf of Uber, filed an antitrust claim against the city for facilitating a violation of the Sherman Act: collective bargaining over wages and working conditions by nonemployee drivers. ${ }^{84}$ After the federal district court sided with the city that its

81. See Sanjukta Paul, Antitrust as Allocator of Coordination Rights, 67 UCLA L.REV. (forthcoming 2020).

82. Vaheesan, supra note 78.

83. United States Chamber of Commerce v. City of Seattle, 274 F. Supp. 3d 1155 (W.D. Wash. 2017).

84. Id. 
ordinance was covered by the state action exemption, ${ }^{85}$ the federal antitrust agencies filed an amicus brief in circuit court alleging that the state action exemption was limited to the customer-facing side of the taxi market and thus did not cover anti-competitive regulation of ride-sharing drivers. ${ }^{86}$ The Ninth Circuit Court of Appeals overturned the district court ${ }^{87}$ setting up an antitrust trial about whether the ridesharing collective bargaining ordinance was, in fact, anti-competitive. The federal agencies further suggested in their brief that if not covered by the state action exemption, driver collective bargaining is a per se violation of the Sherman Act, a naked restraint with no possible pro-competitive justification. ${ }^{88}$

Rather than fight the case on the merits, Seattle modified the ordinance to remove collective bargaining over wages, in the hope of at least salvaging some version of collective bargaining without running afoul of antitrust laws. ${ }^{89}$ But the Chamber has apparently not been satisfied by that significant concession; in renewed filings, it demanded that the ordinance be wholly abandoned, because naming an exclusive bargaining agent for ridesharing drivers amounts to an illegal group boycott against any driver who does not wish to be represented collectively. ${ }^{90}$

At this point, it is clear that the federal agencies are fully behind the use of antitrust laws to undermine worker bargaining power, just as much as they are behind the non-use of the antitrust laws against employer power and control in the fissured workplace. As Sanjukta Paul has pointed out, if the church organist professional organization had, instead of publishing guidelines preventing its members from underbidding one another for gigs, programmed an app to match organists to churches seeking their services, and prevented their members from performing at a church matched to another member via the app, the antitrust authorities would have been just as solicitous of the organists' app as they have been of Uber's price-fixing and market-division business model-provided the organists' app had been operated in the interest of a "for-profit hiring hall" like Uber, as opposed to in the interest of the organists themselves. ${ }^{91}$ That jurisprudence and disposition of enforcement resources effectively means that Uber drivers or organists as workers are paying a significant price to the unitary

85. Id.

86. Brief for the United States and the Federal Trade Commission as Amici Curiae in Support of Appellant and in Favor of Reversal, United States Chamber of Commerce v. City of Seattle, 890 F.3d 769 (9th Cir. 2018) (No. 17-35640) [hereinafter Brief].

87. United States Chamber of Commerce v. City of Seattle, 890 F.3d 769 (9th Cir. 2018).

88. Brief, supra note 86 .

89. Michelle Baruchman, Battle Continues Over Pay, Collective Bargaining for Uber, Lyft Drivers in Seattle, SeATTLE TIMES, December 22, 2018, https://www.seattletimes.com/seattlenews/transportation/battle-continues-over-pay-collective-bargaining-for-uber-lyft-drivers-in-seattle/ [https://perma.cc/XUQ5-RR57]

90. Plaintiff's Motion for Summary Judgment, United States Chamber of Commerce v. City of Seattle, No. 17-cv-00370-RSL (W.D. Wash. March 29, 2019).

91. See Sanjukta Paul, Fissuring and the Firm Exemption 82 LAW \& CONTEMP. Probs., No. 3, 2019, at 65 . 
platforms coordinating the labor market in which those workers sell their services for the privilege of restraining trade and avoiding a free-for-all. ${ }^{92}$ Should any antitrust case against Uber for price-fixing, exclusion, or market division ever see the light of day after Meyer $v$. Kalanick, it's likely that the agencies would take the view that its restraints are vertical and hence subject to the Rule of Reason (as the DOJ has argued in the litigation over no-poaching clauses in franchising contracts $^{93}$ ), rather than per se illegal like non-employee driver collective bargaining. As Sandeep Vaheesan has phrased it, antitrust is about "accommodating capital and policing labor." ${ }^{94}$

\section{CONCLUSION: USING ANTITRUST TO RE-BALANCE POWER IN LABOR MARKETS}

This paper sets out an important but under-appreciated aspect of the rise in labor market precarity and diminishing worker bargaining power: the erosion of antitrust laws restricting dominant firms' ability to use vertical restraints to control and restrict both less powerful affiliates and the workers who work for them, and the concurrent use of antitrust against any attempt by those workers or independent businessmen or contractors to bargain collectively against such concentrations of power. In ascertaining the causes of contemporary inequality in wealth, income, and social status, especially with respect to the labor market, we cannot overlook the role that antitrust has played.

This contrasts with a recent Economic Policy Institute paper by Heidi Shierholz and Josh Bivens that treats the rise of employer power in labor markets, and the extent to which weakening antitrust has caused that phenomenon, as a less important cause of rising inequality and stagnant wages compared to the erosion of labor law and thus of collective bargaining. ${ }^{95}$ Their evidence for the contention that diminishing worker bargaining power matters more than concentrated employer bargaining power is that inequality within the distribution of labor income is a more significant cause of stagnating wages and the growing gap between median worker pay and average worker productivity than is the declining labor share of national income, which is of more recent vintage than either of the first two economic trends.

But we cannot map rising labor income inequality to worker bargaining power and labor law and the declining labor share of income to employer power and antitrust so neatly. As the analysis in Parts II and III show, income inequality

92. See Sanjukta Paul, Antitrust as Allocator of Coordination Rights, 67 UCLA L.REV. (forthcoming 2020).

93. See Boris Bershteyn et al., DOJ Is Trying to Rein In Franchise No-Poach Suits, LAw360 (February 19, 2019), https://www.law360.com/foodbeverage/articles/1130056/doj-is-trying-to-rein-infranchise-no-poach-suits [https://perma.cc/73AW-NW22].

94. Vaheesan, supra note 69.

95. Josh Bivens \& Heidi Shierholz, What Labor Market Changes Have Generated Inequality and Wage Suppression?, ECON. POL'Y INST. (December 12, 2018). 
is to a large extent caused by rising earnings inequality between firms, rather than between workers, reflecting employer power to set wages. This is the result of the legalization of business models like the fissured workplace that allow powerful employers to segregate workers from the profits they earn for their bosses. The point of Part II of this paper is that the fissured workplace is the product of both labor regulation and antitrust. Thus, increasing inequality of power between employers and workers cannot be coherently treated as two separate phenomena: rising employer power, and declining worker power.

That means the solution to unequal bargaining power is not necessarily or not entirely an antitrust solution, but antitrust must play a major part, since it implicates the business models available to the economy's dominant firms. In particular, we should seek, through revived antitrust and labor regulations that both take account of how the economy actually works, and how power is exercised within it, to re-establish the sharp distinction embodied in Richfield Oil. Either workers are employees, in which case they can be controlled by their bosses, who in turn owe them statutory protections including the right to bargain collectively, or they are independent businesses, in which case they cannot be coerced by contract or by any other means. Proposals to extend and strengthen labor law tests for statutory employment to take account of gig economy technologies are crucial, but they will be ineffective so long as employers and lead firms retain the strong incentive to push workers outside their protection. The role of antitrust in that context is to create a significant cost to so doing: the potential for treble damages under antitrust liability should a lead firm be caught coordinating and directing the activities of its non-employee subsidiaries and contractors. That is the mechanism that would weigh against employers' incentive to mis-classify.

Putting such an antitrust regime in place entails the abandonment of both the consumer welfare standard and, with it, the Chicago School's jurisprudence of vertical restraints. Instead, any vertical restraint, price or non-price, should be a presumptive violation of the Sherman Act if it is imposed by a firm with market power. And antitrust's definition of market power must, in turn, be expanded beyond the confined market-share-based Sherman Act jurisprudence to instead take account of the many ways economists have of testing for the existence of market power. Firms would be judged to have market power if they:

- Have the power to unilaterally raise prices for their customers or lower them for their suppliers, including workers;

- Wage- or price-discriminate among customers, suppliers, or workers;

- Unilaterally impose non-price, uncompensated contractual provisions on their counterparties, like non-compete agreements in labor contracts;

- Impede or control entry by would-be competitors; or

- Earn profits and/or make payments to their shareholders at a rate in excess of their market cost of capital. 
All of these things are economic indicia of market power because they could not be done by any one or more firms acting in concert in the face of competition from rivals - therefore they should be legal indicia of market power as well. ${ }^{96}$

Drilling down on how the antitrust laws should target labor market monopsony in particular, not merely prohibit vertical restraints that enable fissured workplace-style business models, the antitrust authorities should bring a monopsonization suit against an online labor platform like Uber that fixes wages and imposes exclusivity on independent businesses, along the lines of Meyer $v$. Kalanick. If, as would be expected, that case would be adjudicated under the Rule of Reason, despite its economic equivalence to the FTC's per se cases against professional organizations and unions of independent contractors, then Congress should streamline the Rule of Reason for labor monopsony. This should be done along the lines proposed by Ioana Marinescu and Eric Posner, setting out principles to guide market definition that are responsive to measured firm-level labor supply elasticities. ${ }^{97}$ In fact, if firms have the unilateral power to dictate wages without causing a significant share of their workforce to leave, then the proper market definition for a monopsonization case may be significantly smaller than the one those authors recommend as a baseline. The point of such a suit is to force Uber to choose one business model or another: either employ the drivers if Uber wants to fix their wages and monitor them on the job, or give up the pricesetting and market coordination power that makes the platform such a value proposition for its investors. It cannot be allowed to do both. Meanwhile, workers themselves who are not statutory employees should be protected by antitrust's labor exemption and should be permitted to bargain collectively. However, any such extension of the labor exemption must not also immunize the powerful employer against whom they would seek to bargain. And at the very least, both no-poaching clauses in franchising contracts and non-compete clauses in employment contracts should be illegal per se..$^{98}$

Finally, analysis of labor market impact should be incorporated in the statutory prospective merger review process that federal agencies undertake as a matter of routine, in order to prevent the harmful accumulation of monopsony power in labor markets by merger. The current FTC Chairman, Joseph Simons, said as much in Congressional testimony in the fall of $2018,{ }^{99}$ but to date there is no evidence that any such investigation has taken place. In the recent merger

96. See Steinbaum \& Stucke, supra note 58.

97. Ioana Marinescu \& Eric A. Posner, A Proposal to Enhance Antitrust Protection Against Labor Market Monopsony (December 21, 2018) (unpublished manuscript) (on file with the Roosevelt Institute).

98. See Petition for FTC Rulemaking to Prohibit Worker Non-Compete Clauses, OPEN MKTS INST. (March 20, 2019), https://openmarketsinstitute.org/wp-content/uploads/2019/03/Petition-forRulemaking-to-Prohibit-Worker-Non-Compete-Clauses.pdf [https://perma.cc/AL4A-MUTV] (petitioning the Federal Trade Commission to undertake an administrative rule-making to make noncompete clauses illegal per se).

99. Oversight of the Enforcement of the Antitrust Laws: Before the Subcommittee on Antitrust, Competition Policy and Consumer Rights of the United States Senate. Committee on the Judiciary, 115th Cong. (October 3, 2018) (statement of Joseph Simons, Chairman of the Federal Trade Commission). 
approval for Staples's takeover of its supplier Essendant, the majority of the commission claimed that the merger would have a pro-competitive impact on input markets. ${ }^{100}$ Specifically, if the combined firm reduced the price it pays to manufacturer, it would in fact purchase more from them, not less, and hence that price reduction would not be an exercise of buyer power (the majority's opinion says nothing about labor specifically as an input). But the idea that the volume of sales is dispositive about the anti-competitive exercise of monopsony power is not correct. Wilmers finds evidence that dominant retailers and manufacturers impose price reductions on the suppliers over whom they exercise market power, and those suppliers in turn pass those price reductions through to their workers in the form of lower wages. ${ }^{101}$ That is an exercise of monopsony power, but it might well be accompanied by greater sales volume from the supplier to the dominant customer.

Altogether, the thesis of this paper is that there is no way to confront the economy's crisis of unequal bargaining power without confronting the role that antitrust has played in getting us there. Antitrust is not a substitute to any of the many other ways that policy ought to be extended to halt and reverse the economy-wide erosion of worker bargaining power behind rising inequality and wage stagnation. But strengthening it is a necessary condition for the success of many of those alternatives, notably, labor law reform and collective bargaining on the part of precariously employed gig economy workers.

100. Statement of Chairman Joseph J. Simons et al., Concerning the Proposed Acquisition of Essendant, Inc. by Staples, Inc., FTC File No. 181-0180 (Jan. 28, 2019), https://www.ftc.gov/system/files/documents/ public_statements/1448328/181_0180_staples_essendant_majority_statement_1-28-19.pdf [https://perma.cc/FZ7L-7DVJ].

101. Nathan Wilmers, Wage Stagnation and Buyer Power: How Buyer-Supplier Relations Affect U.S. Workers' Wages, 1978 to 2014, 83 AMERICAN SOCIOLOGICAL REVIEW 2, 213-42 (2018). 